PREVENTIF: JURNAL KESEHATAN MASYARAKAT

FAKULTAS KESEHATAN MASYARAKAT, UNIVERSITAS TADULAKO

http://jurnal.fkm.untad.ac.id/index.php/preventif

\title{
Sarana Air Bersih Dan Kondisi Jamban Terhadap Kejadian Diare Pada Balita Di Puskesmas Tipo
}

\author{
Jusman Rau ${ }^{1}$, Sri Novita ${ }^{* 1}$ \\ ${ }^{1}$ Departement of Epidemiology, Faculty of Public Health, Tadulako University, Indonesia
}

Author's Email Correspondence (*): srinovita196@gmail.com

Phone : +6282348359074

\begin{abstract}
ABSTRAK
Keadaan sanitasi yang buruk dapat menjadi media penularan berbagai penyakit yang meliputi, pembuangan kotoran, penyediaan air bersih dan sistem pembuangan air limbah. Hal ini dapat memicu terjadinya penyakit menular, seperti Diare. Persentase capaian kasus diare pada tahun 2019 di Puskesmas Tipo sebesar 60,22\%. Tujuan penelitian ini untuk mengetahui pengaruh sarana air bersih dan kondisi jamban terhadap kejadian diare pada balita. Jenis penelitian ini adalah kuantitatif dengan pendekatan cross sectional. Populasi penelitian adalah semua balita di wilayah kerja Puskesmas Tipo sebanyak 1.005, menggunakan rumus Standley Lameshow diperoleh jumlah sampel 113 balita diambil secara stratified random sampling. Data diolah secara univariat, untuk melihat hubungan antara variabel dependen dan independen (bivariat) digunakan uji regresi logistik biner. Hasil penelitian menunjukkan bahwa ada pengaruh antara kualitas air bersih ( nilai sig=0,000) terhadap kejadian diare pada balita, serta tidak ada pengaruh antara jenis sarana air bersih (nilai sig=0,367), risiko pencemaran saran air bersih (nilai sig=0,367), dan kondisi jamban (nilai sig=0,133) terhadap kejadian diare pada balita. Diharapkan kepada masyarakat yang memiliki air yang keruh agar melakukan penyaringan dan dimasak dengan baik terlebih dahulu sebelum air tersebut dikonsumsi.
\end{abstract}

Kata Kunci : Air,Kondisi Jamban,Diare,Balita

Published by:

Tadulako University

Address:

Jl.Soekarno Hatta KM 9. Kota Palu, Sulawesi Tengah, Indonesia.

Phone: +628114120202

Email: Preventif.fkmuntad@gmail.com
Article history :

Received :25 022021

Received in revised form : 25022021

Accepted : 27022021

Available online : 30062021 


\begin{abstract}
Poor sanitation conditions can be a medium for the transmission of various diseases which include sewage, clean water supply, and sewage systems. It can lead to infectious diseases, such as diarrhea. The percentage of diarrhea cases achieved in 2019 at the Tipo Public Health Center was $60.22 \%$. This research aims to determine the effect of a clean water facility and latrine condition on the diarrhea case of toddlers. This research was quantitative with a crosssectional approach. The populations of this research were all toddlers in the working area of Tipo Public Health Center as many as 1.005, using the Standley Lameshow formula, the total samples were 113 toddlers taken by stratified random sampling. The data were processed through univariately in determining the effect between the dependent and independent variables, a binary logistic regression test was used. The results show that there was an effect between the quality of clean water (sig value $=0.000$ ) on the diarrhea case of toddlers, and it does not affect the types of clean water facility ( sig value $=0.367$ ), the risk of contamination for clean water facility ( sig value $=0.367$ ) and latrine condition ( sig $=0.133$ ) on the diarrhea case of toddlers. It is hoped that people will use protected clean water facility and protect the water. For people who have cloudy water, it is necessary to filter and boiled it well before consumption and pay attention to the condition of the latrine for health requirements.
\end{abstract}

Keywords: Water, Latrine, Diarrhea, Toddler.

\title{
PENDAHULUAN
}

Sanitasi lingkungan sebagai bagian penting dari peningkatan derajat kesehatan yang mana pada hakekatnya sanitasi lingkungan adalah kondisi atau keadaan lingkungan yang optimum sehingga berpengaruh positif terhadap status kesehatan yang optimum pula. Sanitasi lingkungan mengutamakan pencegahan terhadap faktor lingkungan sedemikian rupa sehingga munculnya penyakit akan dapat dihindari. Usaha sanitasi dapat berarti pula suatu usaha untuk menurunkan jumlah bibit penyakit yang terdapat di lingkungan sehingga derajat kesehatan manusia terpelihara dengan sempurna. (1)

Negara-negara dengan tingkat pendapatan rendah (low-income countries) air bersih, sanitasi,dan higiene merupakan faktor risiko penyebab penyakit keempat dengan jumlah korban yang meninggal sebanyak 1,6 juta jiwa $(6,1 \%)$. Permasalahan air bersih, sanitasi, dan higiene yang buruk meningkatkan kejadian penyakit diare. Sebagian besar kematian diare di dunia (88\%) disebabkan oleh air, sanitasi, atau higiene. Secara keseluruhan, hampir seluruh kematian ini terjadi di negara-negara berkembang, dan sekitar $84 \%$ diantaranya terjadi pada anak-anak. (2)

Setiap tahun sekitar 525.000 anak balita meninggal akibat diare. Secara global, ada hampir 1,7 miliar kasus penyakit diare pada anak terjadi setiap tahun. Diare biasanya merupakan gejala infeksi pada saluran pencernaan, yang dapat disebabkan oleh berbagai organisme bakteri, 
virus, dan parasit. Infeksi menyebar melalui makanan atau air minum yang terkontaminasi atau dari orang ke orang sebagai akibat dari kebersihan yang buruk. Di seluruh dunia, 780 juta orang tidak memiliki akses air minum yang layak dan 2,5 miliar kekurangan sanitasi yang layak. Di negara berpenghasilan rendah, anak di bawah tiga tahun mengalami rata-rata tiga kali diare setiap tahun. Setiap kejadian diare membuat anak kehilangan nutrisi yang diperlukan untuk pertumbuhan. (3)

Berdasarkan hasil riset kesehatan dasar 2018 (RISKESDAS), prevalensi diare berdasarkan diagnosis nakes dan gejala menurut provinsi pada tahun 2013 - 2018, prevalensi tertinggi berada di Sulawesi Tengah dengan persentase pada tahun 2013 sebesar 8,8\% dan pada tahun 2018 meningkat menjadi sebesar 10,3\%. Sedangkan prevalensi terendah berada di Kepulauan Riau dengan persentase pada tahun 2013 sebesar 3,5\% dan pada tahun 2018 meningkat menjadi sebesar 4,3\%. Target nasional prevalensi diare pada tahun 2013 sebesar $7 \%$ dan pada tahun 2018 sebesar $8 \%$. (4)

Jumlah kasus diare di Sulawesi Tengah pada tahun 2019 sebanyak 52.985 kasus. Jumlah kasus diare tertinggi berada di Kabupaten Parigi Moutong sebanyak 6.941 kasus dan terendah berada di Kabupaten Banggai Laut sebanyak 706 kasus. Kota Palu sendiri berada pada urutan kelima dengan jumlah kasus sebanyak 5.358 kasus. (5)

Persentase capaian kasus diare pada balita di setiap Puskesmas yang ada di Kota Palu pada tahun 2019 didapatkan bahwa, persentase capaian kasus diare pada balita tertinggi berada di Puskesmas Kawatuna sebesar 62,58\% dan terendah berada di Puskesmas Sangurara sebesa 14,78\%. Sedangkan di Puskesmas Tipo persentase capaian kasus diare pada balita sebesar $60,22 \%$. (6)

Diare dapat disebabkan oleh sarana air bersih, yang dimana air sangat dibutuhkan dalam kehidupan sehari-hari seperti mandi, cuci, kakus, dan untuk konsumsi. Sarana air bersih harus memenuhi persyaratan agar air tidak terkontaminasi. Sarana air bersih yang memenuhi persyaratan adalah sumber air terlindungi yang mencakup PDAM, sumur pompa, sumur gali, dan mata air yang terlindungi. (7)

Jenis air bersih yang digunakan untuk keperluan hygiene sanitasi sehari-hari ternyata memberikan pengaruh terhadap potensi risiko terjadinya diare pada balita. Telah banyak penelitian yang menyimpulkan bahwa jenis air bersih berhubungan dengan kejadian diare, khususnya pada balita. Keluarga yang mampu menyediakan air bersih yang sehat, balitanya 
memiliki risiko lebih kecil terkena diare. (8)

Penyebab diare pada manusia erat kaitannya dengan kualitas fisik air yang mereka konsumsi untuk minum dalam kehidupan sehari-hari. Menggunakan air minum yang tercemar dalam hal ini air yang sudah tercemar dari sumbernya atau pada saat disimpan dirumah dapat menyebabkan diare. Kualitas fisik air yang dilihat dari indikator bau, rasa, kekeruhan, suhu, warna, dan jumlah zat padat yang terlarut, secara langsung dapat memicu kandungan bakteriologis dan bahan kimia dalam air. Kejadian ini dapat disebabkan oleh kontaminasi bahanbahan kimia dengan organisme tertentu, terutama jika konsentrasi bahan tersebut dalam dosis yang tinggi, maka dapat menyebabkan diare. (9)

Penggunaan jamban dibeberapa negara membuktikan bahwa upaya penggunaan jamban mempunyai dampak yang sangat besar dalam penurunan terhadap risiko penyakit diare. Keluarga yang tidak mempunyai jamban harus membuat serta menggunakan jamban tersebut sesuai dengan fungsinya.. Penyakit diare dapat ditularkan melalui kotoran manusia, semua orang dalam keluarga harus menggunakan jamban dan jamban harus dalam keadaan bersih agar terhindar dari serangga yang dapat menularkan atau memindahkan penyakit pada makanan. Penggunaan jamban yang sehat dan menjaga kebersihan jamban dapat menurunkan risiko penyakit diare. (10)

Penelitian ini bertujuan untuk mengetahui pengaruh sarana air bersih dan kondisi jamban terhadap kejadian Diare pada balita di wilayah kerja Puskesmas Tipo.

\section{METODE}

Jenis penelitian ini adalah penelitian kuantitatif dengan pendekatan Cross Sectional. Penelitian ini dilakukan di wilayah kerja Puskesmas Tipo yaitu Kelurahan Tipo, Buluri, dan Watusampu pada 5 Juni - 23 Juni 2020. Populasi dalam penelitian ini adalah seluruh balita yang berada di lokasi wilayah kerja Puskesmas Tipo yang berjumlah sebanyak 1.005 balita. Teknik pengambilan sampel pada penelitian ini menggunakan Stratified Random Sampling dengan tingkat kepercayaan sebesar 95\% sehingga didapatkan sampel sebanyak 113 balita. Analisis data yang digunakan adalah analisis data univariat dan bivariat dengan menggunakan uji regresi logistic biner. 


\section{HASIL}

\section{Analisis Univariat}

Tabel 1

Hasil Analisis Univariat

\begin{tabular}{|c|c|c|}
\hline $\begin{array}{c}\text { Usia } \\
\text { Responden } \\
\text { (Tahun) }\end{array}$ & $\mathbf{n}$ & $\%$ \\
\hline $17-21$ & 11 & 9,7 \\
\hline $22-26$ & 34 & 30,1 \\
\hline $27-31$ & 25 & 22,1 \\
\hline $32-36$ & 20 & 17,7 \\
\hline $37-41$ & 12 & 10,6 \\
\hline $42-46$ & 8 & 7,1 \\
\hline $47-51$ & 1 & 0,9 \\
\hline $52-56$ & 2 & 1,8 \\
\hline Jumlah & 113 & 100 \\
\hline $\begin{array}{l}\text { Usia Balita } \\
\text { (Bulan) }\end{array}$ & $\mathbf{n}$ & $\%$ \\
\hline $12-17$ & 31 & 27,4 \\
\hline $18-23$ & 6 & 5,3 \\
\hline $24-29$ & 20 & 17,7 \\
\hline $30-35$ & 7 & 6,2 \\
\hline $36-41$ & 18 & 15,9 \\
\hline $42-47$ & 5 & 4,4 \\
\hline $48-53$ & 19 & 16,8 \\
\hline $54-59$ & 7 & 6,2 \\
\hline Jumlah & 113 & 100 \\
\hline $\begin{array}{l}\text { Jenis Kelamin } \\
\text { Balita }\end{array}$ & $\mathbf{n}$ & $\%$ \\
\hline Laki - Laki & 53 & 46,9 \\
\hline Perempuan & 60 & 53,1 \\
\hline Jumlah & 113 & 100 \\
\hline $\begin{array}{r}\text { Tingkat } \\
\text { Pendidikan }\end{array}$ & $\mathbf{n}$ & $\%$ \\
\hline Tidak Sekolah & 11 & 9,7 \\
\hline Tamat SD & 46 & 40,7 \\
\hline Tamat SMP & 19 & 16,8 \\
\hline Tamat SMA & 32 & 28,3 \\
\hline $\mathrm{S} 1$ & 5 & 4,4 \\
\hline Jumlah & 113 & 100 \\
\hline $\begin{array}{c}\text { Jenis } \\
\text { Pekerjaan }\end{array}$ & $\mathbf{n}$ & $\%$ \\
\hline PNS & 3 & 2,7 \\
\hline Wiraswasta & 4 & 3,5 \\
\hline Petani & 1 & 0,9 \\
\hline $\begin{array}{l}\text { Ibu Rumah } \\
\text { Tangga (IRT) }\end{array}$ & 102 & 90,3 \\
\hline Lainnya & 3 & 2,7 \\
\hline
\end{tabular}




\begin{tabular}{|c|c|c|}
\hline Jumlah & 113 & 100 \\
\hline $\begin{array}{l}\text { Jenis Sarana } \\
\text { Air Bersih } \\
\end{array}$ & $\mathbf{n}$ & $\%$ \\
\hline $\begin{array}{c}\text { Tidak } \\
\text { Terlindungi }\end{array}$ & 29 & 25,7 \\
\hline Terlindungi & 84 & 74,3 \\
\hline Jumlah & 113 & 100 \\
\hline $\begin{array}{c}\text { Risiko } \\
\text { Pencemaran } \\
\text { Sarana Air Bersih } \\
\end{array}$ & $\mathbf{n}$ & $\%$ \\
\hline Risiko Tinggi & 29 & 25,7 \\
\hline Risiko Rendah & 84 & 74,3 \\
\hline Jumlah & 113 & 100 \\
\hline $\begin{array}{l}\text { Kualitas Fisik } \\
\text { Air Bersih }\end{array}$ & $\mathbf{n}$ & $\%$ \\
\hline $\begin{array}{c}\text { Tidak } \\
\text { Memenuhi Syarat } \\
\text { (Keruh) }\end{array}$ & 21 & 18,6 \\
\hline $\begin{array}{l}\text { Memenuhi } \\
\text { Syarat }\end{array}$ & 92 & 81,4 \\
\hline Jumlah & 113 & 100 \\
\hline $\begin{array}{c}\text { Kondisi } \\
\text { Jamban } \\
\end{array}$ & $\mathbf{n}$ & $\%$ \\
\hline $\begin{array}{c}\text { Tidak } \\
\text { Memenuhi Syarat }\end{array}$ & 84 & 73,5 \\
\hline $\begin{array}{l}\text { Memenuhi } \\
\text { Syarat }\end{array}$ & 30 & 26,5 \\
\hline Jumlah & 113 & 100 \\
\hline Kejadian Diare & $\mathbf{n}$ & $\%$ \\
\hline Diare & 51 & 45,1 \\
\hline Tidak Diare & 62 & 54,9 \\
\hline Jumlah & 113 & 100 \\
\hline
\end{tabular}

Sumber : Data Primer,2020

Hasil dari penelitian yang telah dilakukan menunjukkan bahwa dari 113 responden, jumlah responden berdasarkan kelompok usia tertinggi berada pada kelompok usia 22 - 26 tahun sebanyak 34 responden $(30,1 \%)$ dan terendah berada pada kelompok umur 47 - 51 tahun sebanyak 1 responden $(0,9 \%)$. Jumlah responden berdasarkan kelompok usia balita tertinggi berada pada kelompok usia $12-17$ bulan sebanyak 31 balita $(27,4 \%)$ dan terendah berada pada kelompok usia 42 - 47 bulan sebanyak 5 balita (4,4\%). Jumlah balita berjenis kelamin laki-laki sebanyak 53 balita $(46,9 \%)$ dan berjenis kelamin perempuan sebanyak 60 balita $(53,1 \%)$. Jumlah responden berdasarkan tingkat pendidikan tertinggi berada pada tingkat pendidikan tamat SD sebanyak 46 responden $(40,7 \%)$ dan terendah berada pada tingkat pendidikan S1 sebanyak 5 responden $(4,4 \%)$. Jumlah responden berdasarkan jenis pekerjaan, 
tertinggi berada pada ibu rumah tangga sebanyak 102 responden $(90,3 \%)$ dan terendah berada pada petani sebanyak 1 responden $(0,9 \%)$. Sedangkan jumlah responden berdasarkan jenis sarana air bersih, responden yang memiliki jenis sarana air bersih dengan kategori terlindungi sebanyak 84 responden $(74,3 \%)$ dan responden yang memiliki jenis sarana air bersih dengan kategori tidak terlindungi sebanyak 29 responden $(25,7 \%)$.

Jumlah responden berdasarkan risiko pencemaran sarana air bersih, yang memiliki sarana air bersih berisiko rendah terhadap pencemaran sebanyak 84 responden $(74,3 \%)$ dan yang memiliki sarana air bersih berisiko tinggi terhadap pencemaran sebanyak 29 responden (25,7\%). Jumlah responden berdasarkan kualitas fisik air bersih, yang memiliki kualitas air bersih tidak memenuhi syarat sebanyak 21 responden $(18,6 \%)$ dan yang memiliki kualitas air bersih memenuhi syarat sebanyak 92 responden $(81,4 \%)$.Jumlah responden berdasarkan kondisi jamban, responden yang memiliki kondisi jamban yang tidak memenuhi syarat sebanyak 84 responden $(73,5 \%)$ dan yang memiliki kondisi jamban memenuhi syarat sebanyak 30 responden (26,5\%).Jumlah responden yang balitanya mengalami diare sebanyak 51 responden $(45,1 \%)$ dan yang balitanya tidak mengalami diare sebanyak 62 responden $(54,9 \%)$.

\section{Analisis Bivariat}

\section{Tabel 2}

Hasil Analisis Bivariat

\begin{tabular}{|c|c|c|c|c|c|c|c|c|c|}
\hline \multirow{3}{*}{ Variabel } & & \multicolumn{4}{|c|}{ Kejadian Diare } & \multirow{2}{*}{\multicolumn{2}{|c|}{ Total }} & \multirow{3}{*}{ Sig } & \multirow{3}{*}{ OR } \\
\hline & & \multicolumn{2}{|c|}{ Diare } & \multicolumn{2}{|c|}{ Tidak Diare } & & & & \\
\hline & & $\mathbf{n}$ & $\%$ & n & $\%$ & $\mathbf{n}$ & $\%$ & & \\
\hline Jenis & Tidak Terlindungi & 11 & 9,7 & 18 & 15,9 & 29 & 25,7 & \multirow[b]{2}{*}{0,367} & \multirow[b]{2}{*}{0,672} \\
\hline $\begin{array}{c}\text { Sarana Air } \\
\text { Bersih }\end{array}$ & Terlindungi & 40 & 35,4 & 44 & 38,9 & 84 & 74,3 & & \\
\hline $\begin{array}{c}\text { Risiko } \\
\text { Pencemaran }\end{array}$ & Berisiko Tinggi & 11 & 9,7 & 18 & 15,9 & 29 & 25,7 & \multirow[b]{2}{*}{0,367} & \multirow[b]{2}{*}{0,672} \\
\hline $\begin{array}{l}\text { Sarana Air } \\
\text { Bersih }\end{array}$ & Berisiko Rendah & 40 & 35,4 & 44 & 38,9 & 84 & 74,3 & & \\
\hline $\begin{array}{l}\text { Kualitas } \\
\text { Fisik Air }\end{array}$ & $\begin{array}{l}\text { Tidak Memenuhi } \\
\text { Syarat }\end{array}$ & 20 & 17,7 & 1 & 0,9 & 21 & 18,6 & \multirow[t]{2}{*}{0,000} & \multirow[t]{2}{*}{39,355} \\
\hline Bersih & Memenuhi Syarat & 31 & 27,4 & 61 & 54 & 92 & 81,4 & & \\
\hline \multirow{2}{*}{$\begin{array}{l}\text { Kondisi } \\
\text { Jamban }\end{array}$} & $\begin{array}{l}\text { Tidak Memenuhi } \\
\text { Syarat }\end{array}$ & 41 & 36,3 & 42 & 37,2 & 83 & 73,5 & \multirow[t]{2}{*}{0,133} & \multirow[t]{2}{*}{1,952} \\
\hline & Memenuhi Syarat & 10 & 8,8 & 20 & 17,7 & 30 & 26,5 & & \\
\hline
\end{tabular}

Sumber : Data Primer,2020 
Berdasarkan tabel 2 menunjukkan bahwa, dari 29 responden yang memiliki jenis sarana air bersih tidak terlindungi, terdapat 11 balita yang mengalami diare dan 18 balita yang tidak mengalami diare. Sedangkan dari 84 responden yang memiliki sarana air bersih yang terlindungi, terdapat 40 balita yang mengalami diare dan 44 balita yang tidak mengalami diare. Hasil uji statistik menunjukkan bahwa tidak terdapat pengaruh antara jenis sarana air bersih terhadap kejadian diare pada balita di wilayah kerja Puskesmas Tipo. Kemudian, dari 29 responden yang memiliki risiko pencemaran sarana air bersih berisiko tinggi, terdapat 11 balita yang mengalami diare dan 18 balita yang tidak mengalami diare. Sedangkan dari 84 responden yang memiliki risiko pencemaran sarana air bersih yang berisiko rendah, terdapat 40 balita yang mengalami diare dan 44 balita yang tidak mengalami diare. Hasil uji statistik menunjukkan bahwa tidak terdapat pengaruh antara risiko pencemaran sarana air bersih terhadap kejadian diare pada balita di wilayah kerja Puskesmas Tipo. Selanjutnya, dari 21 responden yang memiliki kualitas fisik yang tidak memenuhi syarat, terdapat 20 balita yang tidak mengalami diare dan 1 balita yang tidak mengalami diare. Sedangkan dari 92 responden yang memiliki kualitas fisik air yang memenuhi syarat, terdapat 31 balita yang mengalami diare dan 61 balita yang tidak mengalami diare. Hasil uji statistik menunjukkan terdapat pengaruh antara kualitas fisik air terhadap kejadian diare pada balita di wilayah kerja Puskesmas Tipo. Dan, dari 83 responden yang memiliki kondisi jamban tidak memenuhi syarat, terdapat 41 balita yang mengalami diare dan 42 balita yang tidak mengalami diare. Sedangkan 30 responden yang memiliki kondisi jamban yang memenuhi syarat, terdapat 10 balita yang mengalami diare dan 20 balita yang tidak mengalami diare. Hasil uji statistik menunjukkan bahwa tidak terdapat pengaruh antara kondisi jamban terhadap kejadian diare pada balita di wilayah kerja Puskesmas Tipo.

\section{PEMBAHASAN}

\section{Pengaruh Jenis Sarana Air Bersih terhadap Kejadian Diare pada Balita}

Sumber air minum merupakan salah satu sarana penting dan berkaitan dengan kejadian diare. Sebagian kuman infeksius penyebab diare ditularkan melalui jalur fekal oral, sehingga kuman dapat masuk ke dalam mulut, cairan atau benda yang tercemar dengan tinja misalnya air minum, jari-jari tangan, dan makanan yang disiapkan dalam panci yang dicuci dengan air yang tercemar. (11)

Berdasarkan hasil uji statistik didapatkan nilai Sig. $=0,367$. Oleh karena nilai Sig. > 
0,05 maka dapat ditarik kesimpulan bahwa tidak ada pengaruh antara jenis sarana air bersih terhadap kejadian diare pada balita. Tidak adanya pengaruh antara jenis sarana air bersih terhadap kejadian diare pada balita dikarenakan dominan responden sudah memiliki jenis sarana air bersih yang terlindungi $(74,3 \%)$.

Berdasarkan hasil penelitian didapatkan bahwa masyarakat di wilayah kerja Puskesmas Tipo mengandalkan mata air yang terdapat pada masing-masing kelurahan sebagai sumber air mereka. Namun, terdapat mata air yang tidak terlindungi yang berada di Kelurahan watusampu. Sedangkan di Kelurahan Tipo dan Buluri telah memiliki jenis mata air yang terlindungi.

Hasil penelitian menunjukkan bahwa masih ada balita yang diare dengan sarana air bersih terlindungi. Beberapa hasil penelitian sebelumnya menyatakan bahwa meskipun sarana air yang dimiliki masyarakat masuk dalam kategori sarana air bersih terlindungi, namun apabila tidak memenuhi syarat-syarat kesehatan maka sarana air tersebut berpeluang untuk menyebabkan kejadian diare. Kemudian, didapatkan informasi dari masyarakat bahwa mereka memiliki kebiasaan tidak memasak air.

Masyarakat memiliki kebiasaan tidak memasak air yang dikonsumsi karena mereka percaya bahwa air yang mereka dapatkan dari mata air tersebut aman untuk digunakan. Menurut Hairani, ibu yang tidak memasak air untuk minum, balitanya lebih berisiko 168 kali terkena diare dibanding dengan ibu yang memasak air untuk minum. (12) Apabila dilihat dari distribusi responden berdasarkan tingkat pedidikan, dominan responden memiliki tingkat pendidikan tamat Sekolah Dasar (40,7\%). Pendidikan masyarakat yang rendah akan menjadikan mereka sulit untuk memahami informasi mengenai pentingnya kebersihan perorangan dan sanitasi lingkungan untuk mencegah terjangkitnya penyakit menular, termasuk diantaranya diare. Dengan sulitnya mereka menerima penyuluhan, menyebabkan mereka tidak peduli terhadap upaya pencegahan penyakit menular. (13)

Hasil penelitian ini sejalan dengan temuan Setiyono (14), bahwa tidak ada hubungan antara jenis sumber air bersih dengan kejadian diare. Kualitas air bersih menjadi kunci dari risiko kejadian diare. Jenis sumber air yang digunakan masyarakat berpeluang untuk menyebabkan kejadian diare jika syarat-syarat kesehatannya tidak dipenuhi.

Hasil penelitian ini tidak sejalan dengan temuan Ayuningrum dkk (15), yang menyatakan bahwa keamanan sarana ditinjau dari sisi terlindung dan tidak terlindung menunjukkan pengaruh terhadap kejadian diare. Hasil analisis menunjukkan bahwa 
responden pada rumah tangga yang menggunakan air minum dari sumber tidak terlindung mempunyai risiko untuk terkena diare 1,2 kali lebih besar dibandingkan dengan responden pada rumah tangga yang sumber air minumnya terlindung.

Upaya health promotion dalam five level prevention dapat dilakukan sebagai upaya untuk melakukan pencegahan terhadap kejadian diare. Upaya tersebut dapat berupa pemberian edukasi terkait pentingnya penggunaan sarana air bersih terlindungi dan bagaimana cara melindungi sarana tersebut dari pencemaran sehingga dapat mengurangi risiko kontaminasi pada sarana air bersih.

\section{Pengaruh Risiko Pencemaran Sarana Air Bersih Terhadap Kejadian Diare pada Balita}

Sarana air bersih merupakan bangunan beserta peralatan dan perlengkapannya yang menyediakan dan mendistribusikan air kepada masyarakat. Sarana air bersih harus memenuhi persyaratan kesehatan agar tidak mengalami pencemaran, sehingga dapat diperoleh air yang baik sesuai dengan standar kesehatan. (16).

Berdasarkan hasil uji statistik didapatkan nilai Sig. $=0,367$. Oleh karena nilai Sig. > 0,05 maka dapat disimpulkan bahwa tidak ada pengaruh risiko pencemaran sarana air bersih terhadap kejadian diare pada balita. Tidak adanya pengaruh antara risiko pencemaran sarana air bersih terhadap kejadian diare pada balita dikarenakan dominan sarana air bersih yang dimiliki masyarakat telah memiliki risiko yang rendah terhadap pencemaran (74,3\%). Dalam penelitian ini, sarana air bersih yang diobservasi yaitu mata air. Hasil yang didapatkan, dominan masyarakat telah menggunakan sarana air bersih dengan risiko yang rendah terhadap pencemaran, meskipun begitu masih ada masyarakat yang menggunakan sarana air bersih yang memiliki risiko yang tinggi terhadap pencemaran.

Berdasarkan hasil penelitian didapatkan bahwa masih ada responden dengan risiko pencemaran yang rendah namun balitanya mengalami diare. Meskipun risiko pencemaran yang dimiliki suatu sarana air bersih tergolong rendah, namun tetap perlu dilakukannya pengujian bakteriologi untuk memastikan bahwa air yang digunakan tidak tercemar mulai dari sumber air, proses distribusi, hingga pada penyimpanan dirumah. Kemudian ada pula responden yang tidak mengalami diare dengan sarana air bersih yang berisiko tinggi terhadap pencemaran dikarenakan mereka beranggapan bahwa air yang didapatkan dari mata air tersebut tidak aman untuk digunakan karena lokasinya berdekatan dengan lokasi galian $\mathrm{C}$, sehingga sebelum dikonsumsi mereka menyaring dan memasak air tersebut. Meskipun begitu, masih ada juga responden yang mengaku tidak menyaring dan memasak airnya. 
Dalam penelitian ini, sebagian besar responden memiliki tingkat pendidikan sampai dengan tamat Sekolah Dasar. Pendidikan yang kurang akan menghambat perkembangan sikap seseorang terhadap nila-nilai baru yang diperkenalkan. Sehingga dengan kurangnya pengetahuan seseorang tentang kesehatan tersebut maka resiko terserang penyakit akan lebih besar. Winenti (17) mengungkapkan bahwa tidak terpenuhinya persyaratan konstruksi sarana air bersih yang memenuhi syarat, salah satunya disebabkan oleh kurangnya pengetahuan masyarakat tentang persyaratan sarana air bersih yang memenuhi syarat.

Jarak dengan sumber pencemar merupakan salah satu variabel/item yang dinilai dalam penilaian tingkat risiko pencemaran sarana air bersih atau inspeksi sanitasi sarana air bersih. Semakin banyak penyimpangan pada item penilaian inspeksi sanitasi sarana air bersih berarti bahwa semakin tinggi tingkat risiko pencemaran sarana air bersih tersebut. Tingkat risiko pencemaran sarana air bersih menunjukkan tingkatan atau besarnya kemungkinan sebagai faktor risiko dalam menularkan penyakit. Tidak terpenuhinya atau penyimpangan pada item inspeksi sanitasi sarana air bersih tersebut diatas menyebabkan sarana air bersih tersebut berisiko untuk menularkan penyakit kepada penggunanya (17)

Hasil penelitian ini sejalan dengan temuan Muhadi (16), bahwa tidak ada hubungan yang signifikan antara tingkat risiko pencemaran sarana air bersih dengan kejadian diare pada balita. Kondisi ini dimungkinkan karena air bersih yang ada digunakan balita hanya untuk mencuci peralatan makan yang kemudan dilakukan pemasakan bersamaan dengan botol susu. Untuk kebutuhan gosok gigi, dimungkinkan karena usia yang masih balita sehingga jarang sekali orang tua balita yang membiasakan diri melakukan gosok gigi atau kalau gosok gigi, balita menggunakan air minum/air matang untuk kumur-kumur.

Hasil penelitian ini tidak sejalan dengan temuan Ramadhani dkk (18), yang menunjukkan bahwa terdapat hubungan yang signifikan antara faktor risiko kondisi sarana air bersih dengan kejadian diare. Sebagai dasar penentuan sarana air bersih yang perlu dilakukan pemeriksaan bakteriologis yaitu sarana air bersih dengan tingkat resiko rendah. Sehingga perlu dilakukan pengambilan sampel air untuk mengetahui air yang dihasilkan dari sarana yang digunakan memenuhi syarat kesehatan karena kondisi sarana yang memiliki resiko rendah walaupun persentasenya kecil tetapi memiliki kemungkinan dapat berpengaruh dalam menimbulkan penyakit diare.

Diare dapat terjadi apabila seseorang menggunakan air minum yang sudah tercemar, baik tercemar dari sumbernya, tercemar selama perjalanan sampai ke rumah-rumah, atau 
tercemar pada saat disimpan di rumah. Pencemaran di rumah terjadi apabila tempat penyimpanan tidak tertutup atau apabila tangan yang tercemar menyentuh air pada saat mengambil air dari tempat penyimpanan. Masyarakat yang terjangkau oleh penyediaan air yang benar-benar bersih mempunyai risiko menderita diare lebih kecil dibandingkan dengan masyarakat yang tidak mendapatkan air bersih. Masyarakat dapat mengurangi risiko terhadap serangan diare, yaitu dengan menggunakan air yang bersih dan melindungi air tersebut dari kontaminasi mulai dari sumbernya sampai penyimpanan di rumah (19)

Kegiatan health promotion dalam five level prevention dapat dilakukan dengan memberikan edukasi atau penyuluhan kepada masyarakat, sehingga masyarakat dapat mengetahui faktor-faktor yang dapat mencemari air dan dampak mengonsumsi air yang telah tercemar oleh bakteri ataupun bahan kimia.

\section{Pengaruh Kualitas Fisik Air terhadap Kejadian Diare pada Balita}

Air sebagai salah satu media transmisi penyakit, karena itu perlu untuk diawasi kualitasnya agar nilainya tetap sesuai standar baku mutu kesehatan agar penularan penyakit melalu air dapat dicegah dan dihilangkan. Kebutuhan masyarakat akan air bersih menegaskan bahwa pegawasan air harus dilakukan dengan teliti dan teratur serta perlunya dilakukan tindakan pengawasan serta pencegahan pencemaran sumber-sumber air bersih masyarakat (20)

Berdasarkan uji statistik didapatkan hasil bahwa terdapat pengaruh kualitas air bersih terhadap kejadian diare pada balita dengan nilai Sig. 0,000. Adanya pengaruh antara kualitas air bersih dan kejadian diare pada balita ini dikarenakan air bersih yang dimiliki beberapa responden tidak memenuhi syarat.

Berdasarkan hasil penelitian, ditemukan bahwa masih ada balita yang mengalami diare dengan kualitas air bersih memenuhi syarat secara fisik. Selain berdasarkan parameter fisik, kualitas air juga harus memenuhi persyaratan berdasarkan parameter biologi dan kimia, seperti keberadaan bakteri E. Coli yang dapat menyebabkan terjadinya diare. Penelitian dilakukan pada saat musim penghujan, menurut Sekar Langit (24) bakteri E. Coli biasanya masuk ke dalam air dengan cara pada saat hujan turun, air membawa limbah dari kotoran hewan atau manusia yang kemudian meresap masuk ke dalam tanah melewati pori-pori permukaan tanah atau mengalir dalam sumber air.

Pada penelitian ini, kualitas air bersih dinilai berdasarkan parameter fisik yaitu keruh, rasa, dan bau. Responden yang memiliki kualitas air yang tidak memenuhi syarat dikarenakan 
air bersih yang dimiliki responden memiliki tingkat kekeruhan diatas 25 NTU. Berdasarkan parameter bau dan rasa, tidak ada responden yang memiliki air bersih yang berbau dan berasa. Adapun metode yang digunakan untuk mengukur tingkat kekeruhan yaitu menggunakan turbidity tube. Sedangkan untuk menilai rasa dan bau digunakan metode uji organoleptik. Pengukuran kekeruhan dengan menggunakan turbidity tube dilakukan karena penelitian dilaksanakan pada saat masa pandemi covid-19. Sehingga, tidak tersedia laboratorium yang dapat digunakan untuk mengukur kekeruhan dengan alat yang lebih memadai. Turbidity tube merupakan alat sederhana yang dapat digunakan untuk mengukur kekeruhan, namun dalam penggunaan alat ini memiliki beberapa kelemahan salah satu diantaranya yaitu sensitivitas yang rendah.

Hasil penelitian ini sejalan dengan temuan Rimbawati dkk (21), bahwa ada hubungan antara kualitas fisik air bersih dengan kejadian diare pada balita. Hasil analisa nilai OR di dapatkan 7,268 ( CI 95\% 2,630-20,082) artinya bahwa responden kualitas fisik air yang memenuhi syarat berpeluang 7,268 kali untuk melakukan usaha pencegahan diare dibandingkan dengan kualitas fisik air tidak memenuhi syarat.

Hasil penelitian ini tidak sejalan dengan temuan Elias dkk (22), yang menyatakan bahwa tidak terdapat hubungan antara kualitas fisik air bersih dengan kejadian diare pada balita. Ada beberapa responden yang menggunakan air bersih yang tidak memenuhi syarat (keruh dan berasa) namun air bersih yang tidak memenuhi syarat tersebut tidak langsung di konsumsi oleh responden melainkan di diamkan terlebih dahulu dalam sebuah wadah agar kotoran- kotoran yang ada dalam air dapat terendap ke dasar wadah.

Tindakan yang dapat dilakukan untuk mengurangi dampak dari kualitas air bersih yang tidak memenuhi syarat yaitu general and spesific protection dalam five level prevention yang berupa penyaringan air dengan menggunakan kain pada air yang akan dikonsumsi. Selain itu juga, kegiatan memasak air hingga matang dapat dilakukan untuk menghilangkan bakteri apabila terdapat dalam air.

\section{Pengaruh Kondisi Jamban terhadap Kejadian Diare pada Balita}

Jamban keluarga sangat berguna bagi manusia dan merupakan bagian dari kehidupan manusia, karena jamban dapat mencegah berkembangnya berbagai penyakit saluran pencernaan yang disebabkan oleh kotoran manusia yang tidak dikelola dengan baik. Keberadaan jamban saja tidak cukup untuk mencegah terjadinya penyakit, diperlukan sanitasi jamban yang memenuhi syarat agar penularan penyakit seperti diare dapat terputus (23). 
Berdasarkan uji statistik didapatkan hasil bahwa tidak terdapat pengaruh antara kondisi jamban terhadap kejadian diare pada balita dengan nilai Sig. 0,133. Tidak adanya pengaruh antara kondisi jamban terhadap kejadian diare pada balita dikarenakan banyak responden yang memiliki kondisi jamban tidak memenuhi syarat.

Berdasarkan hasil penelitian, didapatkan bahwa masih ada responden yang balitanya mengalami diare dengan kondisi jamban yang memenuhi syarat. Pada saat dilakukannya wawancara, ada responden yang mengatakan bahwa balitanya masih menggunakan pampers. Kemudian, pampers bekas pakai tersebut bersamaan dengan feses balita dibuang di belakang rumah ataupun tempat sampah yang ada di rumah responden. Fatmawati dkk [24] dalam hasil penelitiannya mengungkapkan bahwa banyak orang beranggapan tinja bayi itu tidak berbahaya. Hal ini tidak benar karena tinja bayi dapat pula menularkan penyakit pada anakanak dan orang tua. Oleh karena itu tinja bayi harus dibuang secara benar.

Selain itu juga, meskipun kondisi jambannya tidak memenuhi syarat namun ada responden yang balitanya tidak mengalami diare. Berdasarkan hasil observasi, didapatkan bahwa jamban yang mereka miliki tidak mencemari sumber air karena jarak antara jamban dan sumber air $>10 \mathrm{~m}$, tersedia air bersih, dan feses yang ada pada jamban juga tidak mudah dijamah oleh vektor dikarenakan jenis jamban merupakan jamban leher angsa sehingga memudahkan feses masuk ke dalam septictank.

Penggunaan jamban dengan jenis leher angsa akan mencegah bau busuk serta masuknya binatang kecil. Sehingga, kondisi jamban yang tidak memenuhi syarat tidak begitu berpengaruh terhadap kejadian diare. Beberapa kriteria dari jamban sehat merupakan faktor determinan diare, seperti keberadaan jamban yang tidak mencemari sumber air, feses yang ada pada jamban tidak mudah dijamah oleh vektor, lantai jamban yang miring ke arah lubang pembuangan, dan tersedianya air bersih (25)

Berdasarkan status pekerjaan responden, maka didapatkan bahwa dominan responden bekerja sebagai ibu rumah tangga $(90,3 \%)$ dan kepala rumah tangganya bekerja sebagai buruh dan petani. Oleh karena itu, masih banyak responden yang memiliki jamban yang tidak memenuhi syarat. Penghasilan yang tinggi memungkinkan anggota keluarga untuk memanfaatkan jamban dengan baik, seperti membangun jamban sehat. Demikian sebaliknya jika penghasilan rendah, maka masyarakat lebih memilih untuk membeli kebutuhan seharihari dibandingkan membangun jamban (26).

Hasil penelitian ini sejalan dengan temuan Putri dkk (27), bahwa tidak ada hubungan 
kondisi jamban dengan kejadian diare. Kondisi sanitasi dasar mungkin tidak memiliki peran lagsung dalam penyebaran diare namun sanitasi dasar dapat menjadi pemicu kejadian diare terutama dalam variabel jamban yang jika pengolahannya tidak tepat maka akan mengontaminasi sumber air yang digunakan sehari-hari dan variabel sampah yang mungkin berhubungan dengan kepadatan lalat sehingga dapat mengontaminasi makanan/minuman.

Hasil penelitian Sekar Langit (28), menyatakan bahwa tidak ada hubungan antara kondisi jamban dengan kejadian diare pada balita. Tempat pembuangan tinja yang tidak memenuhi syarat sanitasi akan meningkatkan risiko terjadinya diare pada anak balita sebesar dua kali lipat dibandingkan dengan keluarga yang mempunyai kebiasaan membuang tinjanya yang memenuhi syarat sanitasi.

Feses pada dewasa atau balita berbahaya karena mengandung virus atau bakteri dalam jumlah besar. Feses balita juga dapat menularkan penyakit pada balita itu sendiri dan juga pada orang tuanya. Selain itu tinja binatang dapat pula menyebabkan infeksi pada manusia. Feces yang dibuang di tempat terbuka dapat digunakan oleh lalat untuk bertelur dan berkembang biak. Lalat berperan dalam penularan penyakit melalui tinja, lalat senang menempatkan telurnya pada kotoran manusia yang terbuka, kemudian lalat tersebut hinggap di kotoran manusia dan hinggap pada makanan manusia. (28)

Upaya yang dapat dilakukan untuk menjaga kondisi jamban agar memenuhi syarat kesehatan yakni dengan melakukan health promotion berupa pemberian informasi terkait syarat jamban sehat dan dampak kesehatan pada kondisi jamban yang tidak memenuhi syarat kesehatan agar masyarakat mau, tau, dan mampu menciptakan jamban sehat.

\section{KESIMPULAN DAN SARAN}

Adapun kesimpulan pada penelitian ini yaitu, tidak terdapat pengaruh antara jenis sarana air bersih, risiko pencemaran sarana air bersih, dan kondisi jamban terhadap kejadian diare pada balita di wilayah kerja Puskesmas Tipo dengan nilai sig. $=0,367(>0,05)$, nilai sig. $=0,367(>0,05)$, nilai sig. $=0,133(>0,05)$. Serta, terdapat pengaruh antara kualitas fisik air bersih terhadap kejadian diare pada balita di wilayah kerja Puskesmas Tipo dengan nilai sig. $=0,000(<0,05)$.

Diharapakan masyarakat membangun sarana air bersih yang terlindungi sesuai dengan syarat kesehatan, untuk meminimalisir terjadinya pencemaran pada sarana air bersih diharapkan masyarakat membersihkan sarana air bersih yang dimiliki secara rutin. Bagi masyarakat yang memiliki air yang keruh, agar melakukan penyaringan sebelum air tersebut 
dimasak. Kemudian, diharapkan bagi masyarakat untuk membangun jamban yang sesuai dengan syarat kesehatan.

\section{DAFTAR PUSTAKA}

1 Bangun H, Nababan D, "Hestina. Hubungan Sanitasi Dasar Dengan Kejadian Diare Pada Balita Di Desa Durian Kecamatan Pantai Labu Kabupaten Deli Serdang Henny Arwina Bangun 1", Donal Nababan 2, Hestina 3. 2020, Vol2, p 1.

2 Prasetyo R, Siagian Th. "Determinan Penyakit Berbasis Lingkungan Pada Anak Balita Di Indonesia (Determinants Of Environmentally Based Diseases Among Children Under Five In Indonesia)". J Kependud Indones. 2017; Vol 12(2), P 93-104.

3 WHO. Diarrhoeal Disease. WHO, 2017.

4 Kementerian Kesehatan RI. Hasil Riset Kesehatan Dasar Utama 2018, 2018.

5 Dinas Kesehatan Provinsi Sulawesi Tengah. Profil Kesehatan Sulawesi Tengah, 2019.

6 Dinas Kesehatan Kota Palu. Profil Dinas Kesehatan Kota Palu, 2019.

7 Kementerian Kesehatan Ri. Data Dan Informasi Profil Kesehatan Indonesia 2016. Kementerian Kesehatan Republik Indonesia, 2017.

8 Syaputra D, Syamsir. "Gambaran Spasial Kejadian Diare Pada Balita Berdasarkan Kondisi Sanitasi Lingkungan Dan Personal Hygiene Di Wilayah Kerja Puskesmas Lempake Kota Samarinda". 2020, Vol1(3), p1905-9.

9 Sukardi, Yusran S, Tina L. Faktor-Faktor Yang Berhubungandengan Kejadian Diare Pada Balitaumur 6-59 Bulan Di Wilayahkerja Puskesmas Poasiatahun 2016. J Ilm Mhs Kesehat Masy. 2017

10 Katiandagho D, Darwel D. "Hubungan Penyediaan Air Bersih Dan Jamban Keluarga Dengan Kejadian Diare Pada Balita Di Desa Mala Kecamatan Manganitu Tahun 2015". J Sehat Mandiri. 2019, Vol 14(2), p 64-78.

11 D Y, Nurjazuli N, Nurpauji S. "Hubungan Jenis Sumber Air, Kualitas Bakteriologis Air, Personal Hygiene Dengan Kejadian Diare Pada Balita Di Wilayah Kerja Puskesmas Lamper Tengah Semarang". J Kesehat Masy Univ Diponegoro. 2015, Vol 3(1), p18474.

12 Hairani B, Suriani S, Andiarsa D, Juhairiyah J. "Hubungan Pengetahuan Ibu Tentang Diare Dan Perilaku Memasak Air Minum Dengan Kejadian Diare Balita Di Puskesmas Baringin Kabupaten Tapin Tahun 2014". J Heal Epidemiol Commun Dis. 2019, Vol 3(1), p 10-4.

13 Riyanto E, Adifa Rfn. "Hubungan Tingkat Pengetahuan, Pendidikan, Dan Pola Hidup Bersih Dan Sehat Ibu Terhadap Kejadian Diare Pada Balita Di Puskesmas Sitopeng Kota Cirebon". J Kedokt Kesehat. 2016, Vol 3(4), p 1-8.

14 Setiyono A. "Faktor Risiko Kejadian Diare Pada Masyarakat Kota Tasikmalaya". J Kesehat Komunitas Indones. 2019, Vol 15(2), p 49-59.

15 Ayuningrum Fv, Salamah M. "Analisis Faktor Sanitasi Dan Sumber Air Minum Yang Mempengaruhi Insiden Diare Pada Balita Di Jawa Timur Dengan Regresi Logistik Biner". Ejournal Its [Internet]. 2016, Vol 4, p 223-8. Available From: Http://Ejurnal.Its.Ac.Id/Index.Php/Sains_Seni/Article/View/10799

16 Muhadi. "Hubungan Kandungan E.Coli Pada Air Minum Dengan Kejadian Diare Pada 
Balita Di Kecamatan Koja Kota Administrasi Jakarta Utara". Univ Indones, 2016

17 Winenti W, Widiyanto T. "Hubungan Pencemaran Sumber Air Dan Perilaku Ibu Dengan Kejadian Diare Pada Anak Balita Di Desa Sirkandi Kecamatan Purwareja Klampok Kabupaten Banjarnegara Tahun 2016". Bul Keslingmas. 2017, Vol 36(4), p 350.

18 Ramadhani Af, Purwanta, Istiono W. "Hubungan Kualitas Sanitasi Dengan Kejadian Diare Pada Keluarga Di Kelurahan Kledung Karang Dalem Kecamatan Banyuurip Kabupaten Purworejo". Ieee Int Conf Acoust Speech, Signal Process. 2017, Vol 41(2), p 84-93.

19 Selomo M, Birawida Ab, Zaenab, Natsir Mf. "Potensi Risiko Kejadian Diare Aibat Kondisi Sanitasi Di Pulau Kecil Kota Makassar". J Nas Ilmu Kesehat ( Jnik ). 2018;1(69):1-10.

20 Zurni Seprina, Eliza Fitria S. "Faktor - Faktor Yang Berhubungan Dengan Kejadian Diare Di Kelurahan Kulim Puskesmas Tenayan Raya:. J Keperawatan Prior [Internet]. 2020, Vol 3(1), $\mathrm{p}$ 66-74. Available From: Http://Jurnal.Unprimdn.Ac.Id/Index.Php/Jukep/Article/View/812

21 Rimbawati Y, Surahman A. "Hubungan Sanitasi Lingkungan Dengan Kejadian Diare Pada Balita". J 'Aisyiyah Med. 2019, Vol 4(2), p 189-98.

22 Elias M, Sondakh R, Rombot D. "Hubungan Antara Sanitasi Lingkungan Dengan Kejadian Diare Pada Balita Di Wilayah Kerja Puskesmas Tahuna Timur Kabupaten Kepulauan Sangihe". 2016, Vol 010, p 1-8.

23 Aolina D. "Hubungan Antara Faktor Lingkungan Dengan Kejadian Diare Pada Masyarakat Di Desa Cintaraja Kecamatan Singaparna Kabupaten Tasikmalaya. Bidekesmas". 2019, Vol 02, p 57-69.

24 Fatmawati Ty, Indrawati Ii, Ariyanto Aa. "Analisis Penggunaan Air Bersih, Mencuci Tangan, Membuang Tinja Dengan Kejadian Diare Pada Balita". J Endur. 2017, Vol 2(3), p 294.

25 Marjuni. "Hubungan Kondisi Sarana Sanitasi Lingkungan Dengan Kejadian Diare Di Lembaga Pemasyarakatan Perempuan Kelas Ii A Sungguminasa". Media Komun Sivitas Akad Dan Masy. 2020, Vol 20(1).

26 Oktanasari W, Laksono B, Indriyanti D. "Faktor Determinan Dan Respon Masyarakat Terhadap Pemanfaatan Jamban Dalam Program Katajaga Di Kecamatan Gunungpati Semarang". Public Heal Perspect J. 2017, Vol 2(3), p 279-86.

27 Putri S, Susanna D. "Kondisi Sanitasi Dasar Dengan Kejadian Diare Di Kawasan Pesisir Pantai Desa Sedari, Kabupaten Karawang, Jawa Barat Tahun 2018". J Nas Kesehat Lingkung Glob. 2020, Vol 1(2), p 115-21.

28 Sekar Langit L. "Hubungan Kondisi Sanitasi Dasar Rumah Dengan Kejadian Diare Pada Balita Di Wilayah Kerja Puskesmas Rembang 2". J Kesehat Masy. 2016, Vol 4(April), p 176-85. 